\title{
Effects of Demographic Structure and Tax Policies on Real Estate Prices
}

\author{
Chung-Fu Lai ${ }^{1}$ \\ ${ }^{1}$ Department of Applied Economics, Fo Guang University, Yilan County, Taiwan \\ Correspondence: Chung-Fu Lai, Associate Professor, Department of Applied Economics, Fo Guang University, No.160, \\ Linwei Rd., Jiaosi, Yilan County 26247, Taiwan.
}

Received: January 20, 2015

Accepted: February 3, 2016

Available online: February 4, 2016

doi:10.11114/aef.v3i2.1355

URL: http://dx.doi.org/10.11114/aef.v3i2.1355

\begin{abstract}
This paper compared the effects of demographic structure and tax policies on real estate prices by using an overlapping generation model under two situations: real estate as an investment good and real estate as a consumption good. We found that both economic growth rate and market interest rate play the important roles in both situations. In the former situation with real estate as an investment good, when the economic growth rate is higher (lower) than the market interest rate, the youth dependency ratio, the elderly population ratio, real estate tax rate, and income tax rate are reversely (positively) correlated with real estate prices. In the latter situation with real estate as a consumption good, the effect of the young dependency ratio and income tax rate on real estate prices reveals a positive (negative) correlation when the economic growth rate is higher (lower) than the market interest rate.
\end{abstract}

Keywords: demographic structure, tax policies, real estate prices, overlapping generation model

\section{Introduction}

Low fertility and society aging are the trends of demographic structure change that global economic development must face in the future, and severe challenges on national finance are the direct impact of demographic structure change. As the young population reduces while the elderly population increases, if the government does not seek to induce people to work longer, the working age population will continue to shrink, and the number of taxpayers reduces. Without updating the tax system, government revenue will reduce significantly to bring extremely huge challenges to sustainable finance. Therefore, tax system reformation (or namely tax raise) will be the one way to secure sustainable finance under low fertility and society aging (such as Japan's consumption tax raises). In other words, demographic structure and tax policies have become two extremely important topics affecting future economic development. In addition, as the real estate is both consumption and investment goods, the research of real estate price is not only an economic issue, but also the important daily life issues, this paper thus investigated the effects of demographic structure and tax policy changes on real estate prices.

From the observation data of the real estate price change in the U.S. by Geltner (2015), it shows a huge boom beginning by 2004, peaking around 2007-08, followed by a tremendous crash bottoming around 2009-10, and then a strong recovery bouncing right out of the trough and continuing through early 2014. Hence this paper focuses on the analysis in the issues of real estate price, and tries to interpret the factors affecting real estate prices, as well as the roles of demographic structure and tax policies. Although existing literature has found many factors affecting real estate prices, very few can elucidate the effect of demographic structure change on real house prices. In earlier times, Muth (1960) analyzed factors determining real house prices in terms of micro-foundations and found that the factors of the distance between the residential area and central business district, unit construction cost, the sales turnover, land use density, and agricultural value will affect real estate prices. Capozza \& Helsley (1989) expanded the scope of research to analyze the problems of family heterogeneous. Since the 1970s, Macroeconomists began to notice the real estate market after the application of econometric approaches and the availability of macroeconomic data increased. For example, Fair (1972) investigating the correlation among real house prices, incomes, and expected future rents, he found that real estate prices rise as incomes and expected rents change. After affirming Fair's (1972) conclusion, Weinberg et al. (1981) further noted that the effect of income rise on real estate prices often occurs after a period of time. Mayo (1981) distinguished the real estate demand of different income scales and found that people begin to care more about the quality than the quantity of housing after their income exceeds a certain amount, thus causing real house prices in prime areas soar much faster and higher than that of the ordinary areas. According to Horioka (1988), instead of the agent 
income, researchers studied real house prices should pay attention to the family income. In addition, as the larger the size of families have higher the demand for non-housing assets, the pushing effect on real house prices comparatively reduces. Ahearne et al. (2005) analyzed the correlation between money supply and real house prices in OECD countries after 1970, they found that the price of real estate and the price of financial assets will rise first as money supply increases, and then the commodity price also rises, finally, the real house prices begin to reduce slowly, and Panagiotidis \& Printzis (2015) and Deng et al. (2015) focus on the macroeconomic determinants of the real estate price.

Although the correlation between demographic factors and real house prices is a hot topic in real estate studies (such as Mankiw \& Weil, 1989; Holland, 1991; McFadden, 1994), as most of researchers emphasized quantitative studies, no well-established theory has been concluded to provide framework for analysis. Mankiw \& Weil (1989) and Holland (1991) were among the earliest to study the effects of birth rate and population scale on real house prices with cross-sectional data and accurately predicted the fall of the US real house market two decades later. Although these articles analyzed related topics from the angle of population scale, none of them considered the possible effects of demographic structure. According to McFadden (1994), baby boom expansion was the cause for $20 \%$ of the rise of actual US real house prices between 1969 and 1989 and would cause the fall of actual US real house prices. Green \& Hendershott (1996) investigated the effects of age structure, education attainment, and income on the family's willingness to pay for securing housing quality using the US 1980 census data and cross-sectional expenditures equations, they found that although the correlation between real house price change and demographic change is insignificant, demographic factors will affect real estate market development indirectly.

In addition, how tax policies affect real estate prices is another topic worthy of research. Due to the capitalization perspective, local public expenditure and tax levying have become the objects of research on the issue of housing. Capitalization occurs due to specific factors that to changes the future profit and affects the current prices of real estate; and falls into positive capitalization and negative capitalization. The former, such as provisions for local public facilities, brings positive effect to real housie prices; and the latter, such as levying property tax, brings negative effect to real house prices. Many researchers studied topics related to capitalization, such as Oates (1969), Bergstrom \& Goodman (1973), Edel \& Sclar (1974), Brueckner (1979, 1983), Reschovsky (1979), Sonstelie \& Portney (1978), Yinger (1982), Carroll \& Yinger (1994), and Man \& Bell (1996), with Oates (1969) and Edel \& Sclar (1974) are comparatively representative studies. Oates (1969) was the pioneer of related research and Edel \& Sclar (1974) proposed that the research period has significant effect on capitalization. From the above literature, it is clear that the difference of the hypothesis, research methods and research variables were the main cause for the inconsistency effect of capitalization.

As we mentioned above, because most studies on the effects of demographic structure or tax structure on real house prices are empirical analysis, and there lacks a complete, well-established theoretical framework, particularly lack of the analysis of the characteristics and the effects of real estate which is both an investment good and a consumption good. After Samuelson (1958) and Diamond (1965) introduced the overlapping generations model, many scholars have since analyzed different topics with the model, including economic growth (such as Uhlig \& Yanagawa, 1996; Yakita, 2003, Zhang \& Lee, 2003; Kawamoto, 2009), trade policy effects (such as Bettendorf \& Heijdra, 2001), the existence, uniqueness, and stability of the long-run equilibrium (such as Galor \& Ryder, 1989; Konishi \& Perera-Tallo, 1997), environmental policy effects (such as Karp \& Rezai, 2014), and the issue of equity and efficiency (such as Piacquadio \& Isaac, 2015). Inclusion of micro-foundations, being simple to understand, and ease of mathematical operation are the characteristics of this model. To investigate the effects of demographic structure and tax structure on real house prices, therefore, this paper considered real estate as an investment good and real estate as a consumption good when applying the discrete-time overlapping generations model set by Samuelson (1958) and Diamond (1965) to analyze the effects of demographic structure and tax policies on real estate prices.

This paper contains five sections. In addition to the introduction, Section 2 proposes a discrete-time overlapping generations model based on real estate as an investment good, Section 3 deduces the effects of demographic structure and tax policies on real estate prices based on real estate as an investment good with comparative static analysis, Section 4 investigates the effects of demographic structure and tax policies on real estate prices also with comparative static analysis after expanding the model to cover real estate as a consumption good, and Section 5 reports the conclusions and recommendations of this paper.

\section{Theoretical Model: Real Estate as an Investment Good}

\subsection{Households}

Referring to the discrete-time overlapping generations model introduced by Samuelson (1958) and Diamond (1965), assumed that there are three different generations in the economic system: the young agent generation, middle-aged agent generation, and old agent generation. For young agents, representative agent does not make any decision, and their consumption is included in that of their parents. That is to say, middle-aged agents (or parents) determine the consumption of young agents. The lifetime utility function of representative agent $i$ is expressed as follows: 


$$
U_{i}=\left(\ln c_{i, t}^{M}+\delta \ln c_{i, t}^{Y}\right)+\beta \pi \ln c_{i, t+1}^{o}
$$

Where $c_{i, t}^{M}$ and $c_{i, t+1}^{O}$ represent respectively the consumption level of agent $i$ born in period $t-1$ in their youth and old age periods, $c_{i, t}^{Y}$ is the consumption level of young agent $i$ born in period $t, \delta$ is the dependency ratio of young agents, $\beta$ is the discount factor, and $\pi$ is the survival ratio of old agents.

Assumed that representative agent earn an income $\left(y_{i, t}\right)$ from work and receive a fixed income transferred from the government $(\bar{T})$, and they consume and invest in bonds $\left(B_{i, t}\right)$ and real estate $\left(R_{i, t}^{M}\right)$ in their middle age. In old age, they retire and consume the accumulated amount from mature bonds $\left(B_{i, t}\right)$ and the capital from selling real estate $\left(R_{i, t}^{O}\right)$. Therefore, the budget constraint of agent born in period $t-1$ in their youth (period $t$ ) and old age (period $t+1$ ) is expressed as follows:

$$
\begin{gathered}
c_{i, t}^{M}+\delta c_{i, t}^{Y}+B_{i, t}+\left(1+\tau_{h}^{M}\right) R_{i, t}^{M}=\left(1-\tau_{y}\right) y_{i, t}+\bar{T} \\
c_{i, t+1}^{O}=((1+r) / \pi) B_{i, t}+R_{i, t+1}^{O}
\end{gathered}
$$

In these equations, $\tau_{h}^{M}$ and $\tau_{y}$ represent respectively the rate of property tax and income tax, and $(1+r) / \pi$ the real return on bond investments.

Assumed that both the bond and real estate markets are perfect, and both the bond and real estate are risk-free assets. Referring to the no-arbitrage principle, the return on real estate must equal the return on bonds, therefore:

$$
R_{i, t}^{O}=((1+r) / \pi)\left(1+\tau_{h}^{M}\right) R_{i, t}^{M}
$$

Combining Eqs. (2), (3), and (4), the following equation is obtained:

$$
c_{i, t}^{M}+\delta c_{i, t}^{Y}+(\pi /(1+r)) c_{i, t+1}^{O}=\left(1-\tau_{y}\right) y_{i, t}
$$

Under the budget constraint (Eq. (5)), the optimal choice for representative agent to pursue the maximization of utility (Eq. (1)) is expressed as follows:

$$
\begin{gathered}
c_{i, t}^{Y}=\delta c_{i, t}^{M} \\
c_{i, t+1}^{O}=\beta(1+r) c_{i, t}^{M}
\end{gathered}
$$

As net bond supply in the equilibrium is zero ( $B_{i, t}=0$ ), the following equations can be obtained after substituting Eq. (5) with Eqs. (6) and (7):

$$
\begin{gathered}
c_{i, t}^{Y}=\delta c_{i, t}^{M}=\frac{1-\tau_{y}}{1+\delta+\beta \pi} y_{i, t} \\
c_{i, t+1}^{O}=\frac{\beta(1+r)\left(1-\tau_{y}\right)}{1+\delta+\beta \pi} y_{i, t} \\
R_{i, t}^{M}=\frac{\beta \pi\left(1-\tau_{y}\right)}{\left(1+\tau_{h}\right)(1+\delta+\beta \pi)} y_{i, t}
\end{gathered}
$$


In Eq. (10), we also use the expression: $\left(1+\tau_{h}\right) R_{i, t}^{M}=\left(1-\tau_{y}\right) y_{i, t}-\left(c_{i, t}^{M}+\delta c_{i, t}^{Y}\right)$.

\subsection{Firms, Government, and Market Equilibrium}

To real estate agents, representative real estate agent supply real estate to maximize profit. In addition, to simplify analysis, we assume that the government transfers all tax revenue to middle-aged agents in a lump-sum fashion. For any period $t$, the net demand on the real estate market of representative agent equals the net supply in the real estate market, we then have:

$$
R_{t}^{M}-\pi R_{t}^{O}=R_{t}^{M}-(1+r) R_{t-1}^{M}=p_{t}(H / n)
$$

Where $p_{t}$ and $H$ represent respectively the price and supply of real estate, and $n$ is the population of young agents and middle-aged agents.

Submitting Eq. (10) with Eq. (11) and assumed that the economic growth rate is $g$ and population growth rate is zero, the following expression is obtained:

$$
p_{t}=\frac{\beta \pi\left(1-\tau_{y}\right)(g-r)}{H\left(1+\tau_{h}\right)(1+\delta+\beta \pi)(1+g)} y_{i, t}
$$

\section{Comparative Static Analysis}

To further investigate the effects of demographic structure (low fertility and society aging) and tax policies (property tax and income tax) on real estate prices, by differentiating Eq. (12) with $\delta, \pi, \tau_{h}$, and $\tau_{y}$, we obtained:

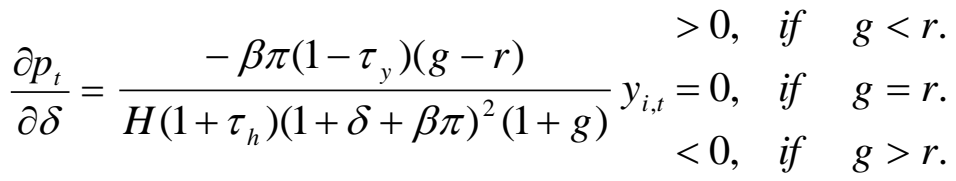

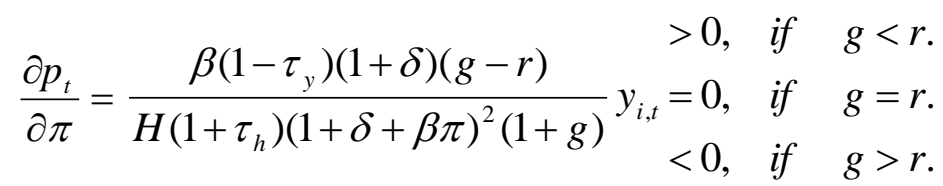

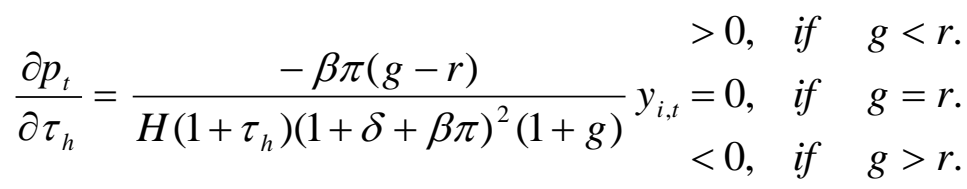

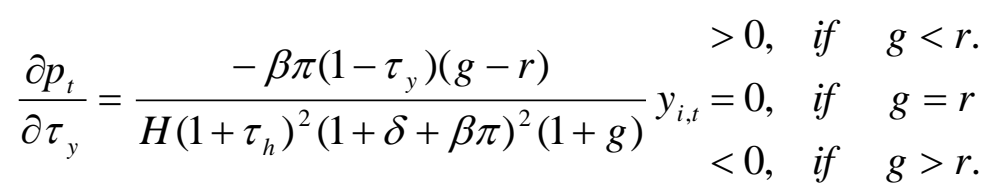

From Eqs.(13) to (16), it is clear that the status of economic growth rate and market interest rate determines the effects of demographic structure (low fertility and society aging) and tax policies (property tax and income tax) on real estate prices. When the economic growth rate is higher than the market interest rate $(g>r)$, real estate prices rise as the dependency ratio of young agents $(\delta)$ and elderly population ratio $(\pi)$ declines, property tax rate $\left(\tau_{h}\right)$ reduces, and income tax rate $\left(\tau_{y}\right)$ reduces. When the economic growth rate equals the market interest rate $(g=r)$, the dependency ratio of young agents $(\delta)$, elderly population ratio $(\pi)$, property tax rate $\left(\tau_{h}\right)$, and income tax rate $\left(\tau_{y}\right)$ will not affect real estate prices. When the economic growth rate is lower than the market interest rate $(g<r)$, the situation is opposite to the economic growth rate is higher than the market interest rate $(g>r)$. The economic implication behind this conclusion is: real estate carries important saving competence as it is also an investment good, as economic growth 
(growth rate is higher than the interest rate) continues, therefore, real estate prices will rise even the dependency ratio of young agents $(\delta)$, the elderly population ratio $(\pi)$, property tax rate $\left(\tau_{h}\right)$ and income tax rate $\left(\tau_{y}\right)$ reduces.

\section{Theoretical Model: Real Estate as a Consumption Good}

Considering a case of the real estate as a consumption good, after introducing real estate consumption to the utility function, the utility function will become as follows:

$$
U_{i}=\left(\ln c_{i, t}^{M}+\delta \ln c_{i, t}^{Y}+\ln h_{i, t}^{M}\right)+\beta \pi\left(\ln c_{i, t+1}^{O}+\ln h_{i, t+1}^{O}\right)
$$

Likewise, assumed that consumers can earn an income and invest in bonds and real estate only in the middle-aged period, the budget constraint can be expressed as follows:

$$
\begin{gathered}
c_{i, t}^{M}+\delta c_{i, t}^{Y}+B_{i, t}+\left(1+\tau_{h}^{M}\right) p_{t} h_{i, t}^{M}=\left(1-\tau_{y}\right) y_{i, t} \\
c_{i, t+1}^{O}=((1+r) / \pi) B_{i, t}+p_{t+1} h_{i, t}^{M}
\end{gathered}
$$

By using budget constraints (Eqs. (18) and (19)) and utility function (Eq. (17)), and assumed that $p_{t}=p_{t+1}=\bar{p}$, the optimal choice for real estate consumption to pursuit the maximization of utility is as follows:

$$
h_{i, t}^{M}=\frac{2(1+r)\left(1-\tau_{y}\right)\left(1+\tau_{h}\right)-\pi}{\bar{p}(1+r)(1+\delta+\beta \pi)} y_{i, t}
$$

In the equilibrium, real estate supply in any period $t$ satisfies $H=n h_{i, t}^{M}+n \pi\left(h_{i, t}^{O}-h_{i, t-1}^{M}\right)$. Also, assumed that the economic growth rate is $g$ and the population growth rate is zero, we then have:

$$
\bar{p}=\frac{\left(1-\tau_{y}\right)(g-r)}{H\left(2\left(1+\tau_{h}\right)-(\pi /(1+r))\right)(1+\delta+\beta \pi)(1+g)} y_{i, t}
$$

Likewise, by differentiating Eq. (21) with $\delta, \pi, \tau_{h}$, and $\tau_{y}$, we obtained:

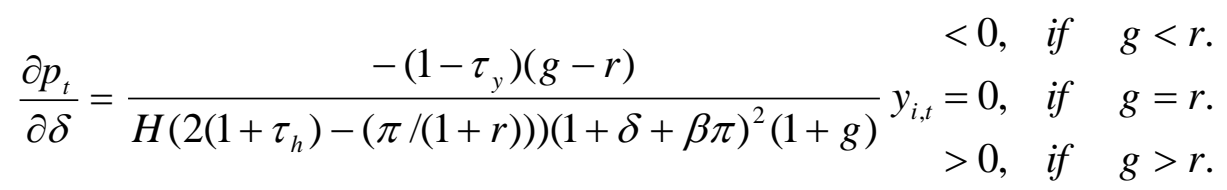

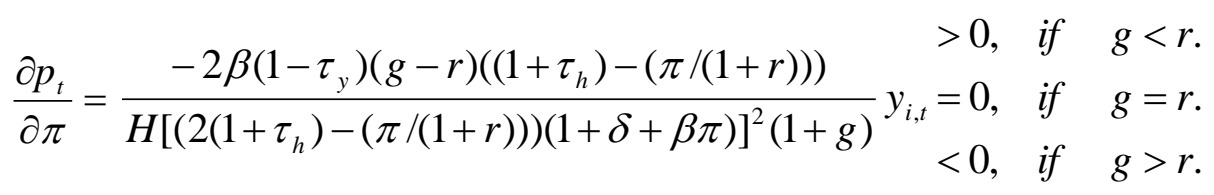

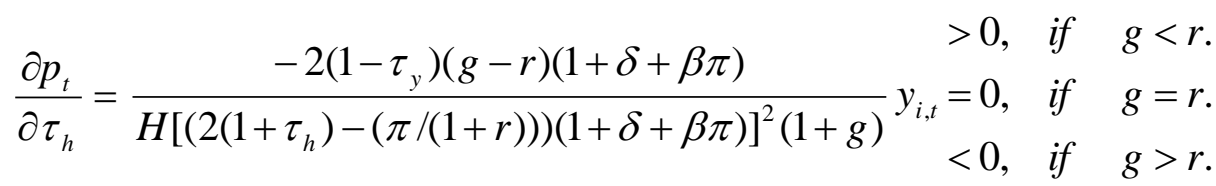

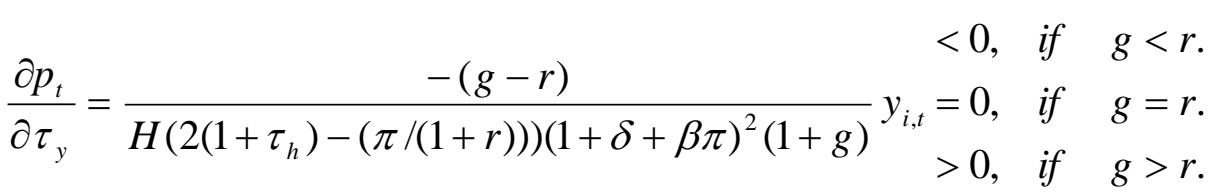

From Eqs. (22) to (25), it is clear that when real estate is a consumption good, the effects of the elderly population ratio $(\pi)$ and property tax rate $\left(\tau_{h}\right)$ on real estate prices is generally consistent, but the effects of the dependency ratio of young agents $(\delta)$ and income tax rate $\left(\tau_{y}\right)$ on real estate prices exist the difference as compared to the case of the real estate as an investment good. When the economic growth rate is higher than the market interest rate $(g>r)$, real 
estate prices will fall as the dependency ratio of young agents $(\delta)$ and income tax rate $\left(\tau_{y}\right)$ declines. When the economic growth rate equals the market interest rate $(g=r)$, the dependency ratio of young agents $(\delta)$ and income tax rate $\left(\tau_{y}\right)$ will not affect real estate prices. When the economic growth rate is lower than the market interest rate $(g<r)$, real estate prices will rise as the dependency ratio of young agents $(\delta)$ and income tax rate $\left(\tau_{y}\right)$ declines. This is because real estate consumption enters the utility function. Therefore, as long as the economic growth rate is high enough (higher than the interest rate level), even the dependency ratio of young agents $(\delta)$ and income tax rate $\left(\tau_{y}\right)$ rises, people tend to buy more real estate when they are young to plan for their later life, hence the real estate demand increases, and the higher the real estate prices will be.

We then do a quantitative exercise to verify the effects of demographic structure and tax policies changes on real estate prices. Similarly to the work of Sommery \& Sullivan (2014), the parameters adopted for the simulation in this paper are mostly fit the actual data for the U.S. First, following the literature of Sommery \& Sullivan (2014), the subjective discount factor $(\beta)$ is set equal to 0.99 , the average U.S. income tax rate $\left(\tau_{y}\right)$ was estimated at close to $10 \%$ (see CBO, 2010), and using data from American Community Survey Reports (2008), housing property tax rate $\left(\tau_{h}\right)$ is set to $0.95 \%$. In addition, because housing supply is relatively inelastic (see Sommery \& Sullivan, 2014), this paper sets the real estate supply growth rate $(H)$ to be 1 , income $\left(y_{i, t}\right)$ also set to 1 . Finally, using the data from the National Vital Statistics Reports (2015), birth rate $(\delta)$ and survival rate $(\pi)$ are set to 0.6 and 0.99 , respectively. And because the focus of this paper are the parameters of economic growth rate $(g)$ and interest rate $(r)$, for the simulation, values in $1 \%, 2 \%$, and $3 \%$ are successively taken. The parameter values are summarized in Table 1 , and the results of numerical simulations are as shown in Table 2.

Table 1. Choice of the parameter values

\begin{tabular}{ccc}
\hline Symbol & Description & Value \\
\hline$\beta$ & Subjective discount factor & 0.99 \\
\hline$\delta$ & Dependency ratio of young agents & 0.6 \\
\hline$\pi$ & Survival ratio of old agents & 0.99 \\
\hline$\tau_{y}$ & Rate of income tax & $10 \%$ \\
\hline$\tau_{h}$ & Rate of property tax & $0.95 \%$ \\
\hline$H$ & Real estate supply growth rate & 1 \\
\hline$g$ & Economic growth rate & $1 \% ; 2 \% ; 3 \%$ \\
\hline$r$ & Interest rate & $1 \% ; 2 \% ; 3 \%$ \\
\hline
\end{tabular}

Table 2. The results of numerical simulations

Model 1: Real Estate as an Investment Good

\begin{tabular}{|c|c|c|c|c|c|c|c|c|c|c|c|c|}
\hline & & $\frac{\partial p_{t}}{\partial \delta}$ & & & $\frac{\partial p_{t}}{\partial \pi}$ & & & $\frac{\partial p_{t}}{\partial \tau_{h}}$ & & & $\frac{\partial p_{t}}{\partial \tau_{y}}$ & \\
\hline$r$ & $1 \%$ & $2 \%$ & $3 \%$ & $1 \%$ & $2 \%$ & $3 \%$ & $1 \%$ & $2 \%$ & $3 \%$ & $1 \%$ & $2 \%$ & $3 \%$ \\
\hline$g=1 \%$ & 0 & 0.0013 & 0.0026 & 0 & 0.0013 & 0.0026 & 0 & 0.0014 & 0.0029 & 0 & 0.0013 & 0.0026 \\
\hline$g=2 \%$ & -0.0013 & 0 & 0.0013 & -0.0013 & 0 & 0.0013 & -0.0014 & 0 & 0.0014 & -0.0013 & 0 & 0.0013 \\
\hline$g=3 \%$ & -0.0026 & -0.0013 & 0 & -0.0026 & -0.0013 & 0 & -0.0028 & -0.0014 & 0 & -0.0025 & -0.0013 & 0 \\
\hline
\end{tabular}

Model 2: Real Estate as a Consumption Good 


$$
\frac{\partial p_{t}}{\partial \delta} \quad \frac{\partial p_{t}}{\partial \pi} \quad \frac{\partial p_{t}}{\partial \tau_{h}} \quad \frac{\partial p_{t}}{\partial \tau_{y}}
$$

\begin{tabular}{|c|c|c|c|c|c|c|c|c|c|c|c|c|}
\hline$r$ & $1 \%$ & $2 \%$ & $3 \%$ & $1 \%$ & $2 \%$ & $3 \%$ & $1 \%$ & $2 \%$ & $3 \%$ & $1 \%$ & $2 \%$ & $3 \%$ \\
\hline$g=1 \%$ & 0 & -0.018 & -0.039 & 0 & 0.003 & 0.008 & 0 & 0.193 & 0.429 & 0 & -0.02 & -0.043 \\
\hline$g=2 \%$ & 0.017 & 0 & -0.018 & -0.002 & 0 & 0.004 & -.173 & 0 & 0.212 & 0.018 & 0 & -0.02 \\
\hline$g=3 \%$ & 0.032 & 0.017 & 0 & -0.004 & -0.003 & 0 & -0.343 & -0.19 & 0 & 0.035 & 0.018 & 0 \\
\hline
\end{tabular}

As known from the Table 2, we can recertify the effects of demographic structure and tax policies on real estate prices in the cases of real estate as an investment good and real estate as a consumption good

\section{Conclusions and Recommendations}

Declining labor population due to low fertility rate accompanied with rising retired elderly population is the common demographic structure problem across the world, and financial source sustainability is the problem resulting from low fertility and society aging. In addition, as there lacks theoretical research of factors affecting demographic structure change, this paper investigated the effect of demographic structure change and tax policies on real estate prices under two situations: real estate as an investment good and real estate as a consumption good, with the discrete-time overlapping generations model.

Through theoretical derivation, we found that economic growth rate and market interest rate play considerably important roles in how demographic structure and tax policies affect real estate prices. For example, when the economic growth rate is higher than the market interest rate and real estate is an investment good, the real estate prices would rise as the dependency ratio of young agents and the elderly population ratio reduces, property tax rate and income tax rate reduces. When the real estate is a consumption good, the effects of the dependency ratio of young agents and income tax rate on real estate prices exist the difference. That is to say, when the real estate is a consumption good, real estate prices will fall as the dependency ratio of young agents and income tax rate decreases.

This paper aims to propose a simple and easy to understand theoretical framework among a great number of empirical studies, so as to supplement the research of real estate issue. To simply analysis, however, altruism was eliminated, which is the limitation of this paper. This limitation can be one of the topics in future research.

\section{References}

Ahearne, A. G., Ammer, J., Doyle, B. M., Kole, L. S., \& Martin, R. F. (2005). House Prices and Monetary Policy: A Cross Country Study. International Finance Discussion Papers, 841. http://dx.doi.org/10.2139/ssrn.816946

American Community Survey Reports. (2008). Income, Earnings, and Poverty Data From the 2007 American Community Survey. U.S. Department of Commerce.

Bergstrom, T. C., \& Goodman, R. P. (1973). Private Demands for Public Goods. American Economic Review, 63(3), 280-296.

Bettendorf, L. J. H., \& Heijdra, B. J. (2001). Intergenerational Welfare Effects of a Tariff under Monopolistic Competition. Journal of Economics, 73(3), 313-346. http://dx.doi.org/10.1007/BF01257926

Brueckner, J. K. (1979). Property Value, Local Public Expenditure and Economic Efficiency, Journal of Public Economics, 11(2), 223-245. http://dx.doi.org/10.1016/0047-2727(79)90006-9

Brueckner, J. K. (1983). Property Value Maximization and Public Sector Efficiency. Journal of Urban Economics, 14(1), 1-15. http://dx.doi.org/10.1016/0094-1190(83)90026-8

Capozza, D. R., \& Helsley, R. W. (1989). The Fundamentals of Land Prices and Urban Growth. Journal of Urban Economics, 26(3), 295-306. http://dx.doi.org/10.1016/0094-1190(89)90003-X

Carroll, R. J., \& Yinger J. (1994). Is the Property Tax a Benefit Tax? The Case of Rental Housing. National Tax Journal, 47(2), 295-316.

CBO. (2010). Average federal tax rates in 2007. Congrational Budget Office.

Deng, Y., Girardin, E., \& Joyeux, R. (2015). Fundamentals and the Volatility of Real Estate Prices in China: A 
Sequential Modelling Strategy. HKIMR Working Paper, No. 22. http://dx.doi.org/10.2139/ssrn.2689387

Diamond, P. A. (1965). National Debt in a Neoclassical Growth Model. American Economic Review, 55, 1126-1150.

Edel, M., \& Sclar, F. (1974). Taxes, Spending and Property Values: Supply Adjustments in a Tiebout-Oates Model. Journal of Political Economy, 82(5), 941-954. http://dx.doi.org/10.1086/260248

Fair, R. C. (1972). Disequilibrium in Housing Models. Journal of Finance, 27(2), 207-221. http://dx.doi.org/10.2307/2978470

Galor, O. \& Ryder, H. E. (1989). Existence, Uniqueness, and Stability of Equilibrium in an Overlapping-Generation Model with Productive Capital. Journal of Economic Theory, 49(2), 360-375. http://dx.doi.org/10.1016/0022-0531(89)90088-4

Geltner, D. (2015). Real Estate Price Indices \& Price Dynamics: An Overview from an Investments Perspective. Annual Review of Financial Economics, 7(1), 615-633. http://dx.doi.org/10.1146/annurev-financial-111914-041850

Green, R., \& Hendershott, P. (1996). Age, Housing Demand, and Real House Prices. Regional Science and Urban Economics, 26(5), 465-480. http://dx.doi.org/10.1016/0166-0462(96)02128-X

Holland, A. S. (1991). The Baby Boom and the Housing Market. Regional Science and Urban Economics, 21(4), 565571. http://dx.doi.org/10.1016/0166-0462(91)90020-N

Horioka, C. Y. (1988). Tenure Choice and Housing Demand in Japan. Journal of Urban Economics, 24(3), 289-309. http://dx.doi.org/10.1016/0094-1190(88)90030-7

Karp, L., \& Rezai, A. (2014). The Political Economy of Environmental Policy with Overlapping Generations. International Economic Review, 55(3), 711-733. http://dx.doi.org/10.1111/iere.12068

Kawamoto, K. (2009). Status-Seeking Behavior, the Evolution of Income Inequality, and Growth. Economic Theory, 39(2), 269-289. http://dx.doi.org/10.1007/s00199-007-0318-4

Konishi, H., \& Perera-Tallo, F. (1997). Existence of Steady-State Equilibrium in an Overlapping-Generations Model with Production. Economic Theory, 9(3), 529-537. http://dx.doi.org/10.1007/BF01213853

Man, J. Y., \& Bell, M. E. (1996). The Impact of Local Sales Tax on the Value of Owner-Occupied Housing. Journal of Urban Economics, 39(1), 114-130. http://dx.doi.org/10.1006/juec.1996.0006

Mankiw, N. G., \& Weil, D. N. (1989). The Baby Boom, the Baby Bust, and the Housing Market. Regional Science and Urban Economics, 19(2), 235-258. http://dx.doi.org/10.1016/0166-0462(89)90005-7

Mayo, S. K. (1981). Theory and Estimation in the Economics of Housing Demand. Journal of Urban Economics, 10(1), 95-116. http://dx.doi.org/10.1016/0094-1190(81)90025-5

McFadden, D. (1994). Demographics, the Housing Market, and the Welfare of the Elderly. Studies in the Economics of Aging, University of Chicago Press: Chicago, 225-285.

Muth, R. F. (1960). The Demand for Non-Farm Housing. In Arnold C. Harberger, edited., The Demand for Durable Goods.

National Vital Statistics Reports. (2015). Fetal and Perinatal Mortality: United States, 2013.

Oates, W. E. (1969). The Effect of Property Taxes and Local Public Spending on Property Values: An Empirical Study of Tax Capitalization and the Tiebout Hypothesis. Journal of Political Economy, 77(6), 957-971. http://dx.doi.org/10.1086/259584

Panagiotidis, T., \& Printzis, P. (2015). On the Macroeconomic Determinants of the Housing Market in Dreece: A VECM Approach. GreeSE Paper, No. 88

Piacquadio, P. G. \& Isaac, T. (2015). Equity and Efficiency in an Overlapping Generation Model. Social Choice and Welfare, 44(3), 549-565. http://dx.doi.org/10.1007/s00355-014-0848-1

Reschovsky, A. (1979). Residential Choice and the Local Public Sector: An Alternative Test of the Tiebout Hypothesis. Journal of Urban Economics, 6(4), 501-520. http://dx.doi.org/10.1016/0094-1190(79)90027-5

Samuelson, P. A. (1958). An Exact Consumption Loan Model of Interest with or without the Social Contrivance of Money. Journal of Political Economy, 66(6), 467-482. http://dx.doi.org/10.1086/258100

Sommery, K., \& Sullivan, P. (2014), Implications of U.S. Tax Policy for House Prices, Rents, and Homeownership. Federal Reserve Board of Governors.

Sonstelie, J. C., \& Portney, P. R. (1978). Profit Maximizing Communities and the Theory of Local Public Expenditures. Journal of Urban Economics, 5(2), 263-277. http://dx.doi.org/10.1016/0094-1190(78)90028-1 
Uhlig, H., \& Yanagawa, N. (1996). Increasing the Capital Income Tax May Lead to Faster Growth. European Economic Review, 40(8), 1521-1540. http://dx.doi.org/10.1016/0014-2921(96)00032-3

Weinberg, D. H., Friedman, J. M., \& Stephen, K. M. (1981). Intraurban Residential Mobility: The Role of Transactions Costs, Market Imperfections, and Household Disequilibrium. Journal of Urban Economics, 9(3), 332-348. http://dx.doi.org/10.1016/0094-1190(81)90031-0

Yakita, A. (2003), Taxation and Growth with Overlapping Generations. Journal of Public Economics, 87(3-4), 467-487. http://dx.doi.org/10.1016/S0047-2727(01)00083-4

Yinger, J. (1982). Capitalization and the Theory of Local Public Finance. Journal of Political Economy, 90(5), 917-943. http://dx.doi.org/10.1086/261101

Zhang, J., Zhang, J., \& Lee, R. (2003). Rising Longevity, Education, Savings, and Growth. Journal of Development Economics, 70(1), 83-101. http://dx.doi.org/10.1016/S0304-3878(02)00088-3

\section{(c) $\mathrm{EY}$}

This work is licensed under a Creative Commons Attribution 3.0 License. 